\title{
sciendo
}

ISSN: $1231-4005$

e-ISSN: 2354-0133

DOI: $10.2478 /$ kones-2019-0095

\section{ANALYSIS OF ELECTRIC VEHICLES EFFICIENCY AND THEIR INFLUENCE ON ENVIRONMENTAL POLLUTION}

\author{
Mirosław Karczewski, Leszek Szczęch, Filip Polak, Szymon Brodowski \\ Military University of Technology \\ Faculty of Mechanical Engineering \\ Institute of Motor Vehicles and Transportation \\ Gen. Sylwestra Kaliskiego Street 2, 00-908 Warsaw, Poland \\ e-mail:miroslaw.karczewski@wat.edu.pl,leszek.szczech@wat.edu.pl \\ filip.polak@wat.edu.pl,szymon.brodowski@student.wat.edu.pl
}

\begin{abstract}
Electric vehicles are increasingly present on the roads of the whole world. They have the opinion of ecological vehicles, not polluting the environment. Society is more and more often persuaded to buy electric cars as an environmentally friendly solution but is this for sure? Electric cars need quite a lot of electricity accumulated in batteries to drive on a long range. During the charging process, this energy is obtained from the electricity network, to where it is supplied by power plant. Electricity production from renewable sources is a privilege for the rare. However, electric cars are charged from the electricity grid, which in large part energy comes from non-renewable fuels. The efficiency of energy production in power plants and the energy transmission and conversion chain causes that only part of the energy produced in this way goes to the vehicle's wheels. Although the power plants are equipped with more and more efficient exhaust gas cleaning systems, they do not clean them up to 100\%. Sulphur, nitrogen, mercury and heavy metals remain in the exhaust. The article is an attempt to answer the question whether the total emission of toxic components associated with the use of an electric vehicle is not bigger than in a traditional internal combustion engine.
\end{abstract}

Keywords: electric vehicle, exhaust gas toxic components, electro power plants, electricity production

\section{Introduction}

Currently, more and more attention is paid to energy technologies environmentally friendly. The acquisition of electricity from renewable energy sources such as solar radiation, wind or water energy is an increasingly common challenge. One of the important factors affecting the natural environment is cars, used daily in mass quantities. According to data of the Central Statistical Office, in 2017 over 28 million cars were registered in Poland, including approx. 22 million passenger cars, of which about 13.5 million have passed technical tests and bought car insurance [6].

Society is more and more often persuaded to buy electric cars as an environmentally friendly solution. Electric cars need quite a lot of electricity accumulated in batteries to drive on a long range. During the charging process, this energy is obtained from the electricity network, to where it is supplied by power plant. The dominant share of electricity production from non-renewable sources is a problem. Nearly $85 \%$ of the energy market is coal-fired power plants powered by bituminous coal and lignite, and ca. $5 \%$ is covered by gas-turbine power plants operating on natural gas. Power plants produce exhaust gas in which toxic compounds, heavy metals, and particulate matters are contained. Their quantity and quality depends on the type of power plant, installed exhaust gas cleaning systems and on the level of electricity production. Another problem is the low efficiency of electricity transmission to consumers. Only $85-88 \%$ of the energy generated in the power plant is delivered to the vehicle charging point, where the battery is charged. In addition, even less energy goes to the vehicles' drive wheels. Transmission lines, charging stations, electric motors and electrical converters in the vehicle have their efficiency. The 
various stages of energy transformation cause an increase for compounds produced to the environment related to the distance travelled by the electric vehicle. It can therefore turn out that the use of an electric vehicle results in a greater total emission of chemicals than in a car with an internal combustion engine. Which means that electric cars cannot pass the emission standards (Euro 6).

\section{Characteristics of selected cars with electric drive}

Electric vehicles are driven by electricity stored in a traction battery or taken from a fuel cell that generates electricity from fuel carried in the vehicle and oxygen from the air or from the traction network close to the vehicle's driving path. The drive motors are DC or AC electric motors that can operate both in motor and generator mode (i.e. recovering energy during braking). Electric combustion engines at the beginning of the automotive industry were used as readily as combustion engines. The first vehicle to overcome the $100 \mathrm{~km} / \mathrm{h}$ barrier was an electric vehicle. The large mass of batteries needed to store energy, their low durability and long charging time discouraged vehicle users until the end of the 20th century, the renaissance of electric cars.

Nowadays, the leaders producing electric cars are Hyundai with the Ioniq Electric, Nissan with Leaf and Tesla with the S model. It is believed that these types of vehicles are future-proof, due to their low cost of ownership and environmental friendliness. The article estimates the emission of toxic compounds associated with their use in order to assess the degree of impact of these electric vehicles on the natural environment.

Electric vehicles have many advantages and disadvantages. Basic advantages can include, for example:

- low cost of ownership,

- easy cooling of electric motor,

- lack of lubrication system of electric motor,

- basic construction, easy to control,

- low level of noise and vibration,

- lack of exhaust gas (on the road).

Main disadvantages are:

- range of the vehicle is low, it should be charged every $200-300 \mathrm{~km}$,

- lack of charging stations,

- long time for recharging,

- high cost of buying an electric car,

- fast aging and diminish of battery capacity,

- high cost of battery replacing.

In the presented analyses of toxic compounds emissions, three models of electric cars were considered, to which further stages of work were devoted. These are Hyundai IONIQ ELECTRIC, Nissan LEAF, Tesla Model S.

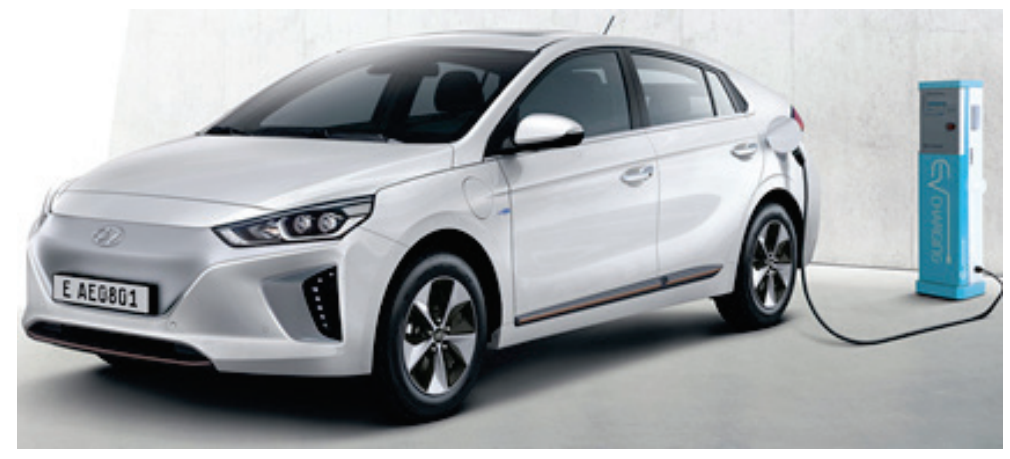

Fig. 1. An electric car-Hyundai IONIQ [8] 


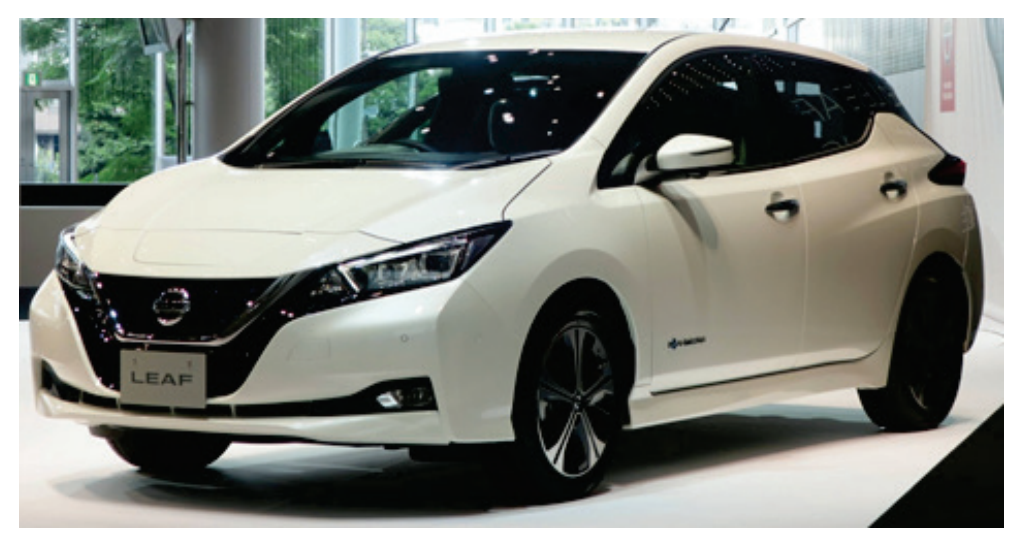

Fig. 2 Nissan LEAF electric car [9]

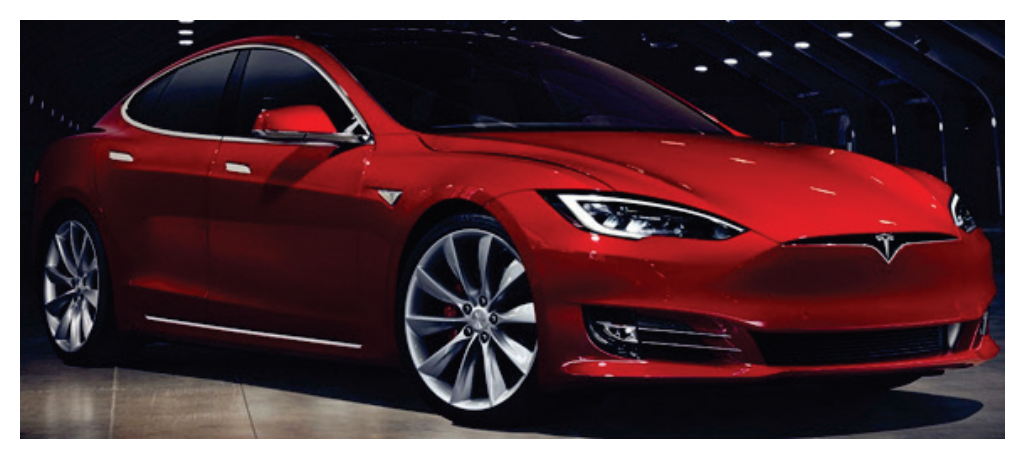

Fig. 3 Tesla Model S electric car [11]

Hyundai IONIQ ELECTRIC is a sedan car, with front-wheel drive, five-person, five-door, compact class. Nissan LEAF is a hatchback car, with front-wheel drive, five-person, five-door, compact class and The Tesla Model $\mathrm{S}$ is a lift back passenger car with rear-wheel drive, fiveperson, five-door, premium class.

The electric cars presented above are different in terms of weight, engine power and battery capacity. Tesla stands out here in a special way, as it is part of the segment of luxury cars, but also costs almost twice as much as the other two.

Tab. 1. Basic data of Hyundai IONIQ electric car [8]

\begin{tabular}{|c|c|}
\hline \multicolumn{2}{|c|}{ Electric motor } \\
\hline Type & Synchronous with permanent magnets \\
\hline Effective power $(\mathrm{kW})$ & 88 \\
\hline Torque $(\mathrm{Nm})$ & 295 \\
\hline \multicolumn{2}{|c|}{ Battery } \\
\hline Type of battery & Lithium-ion polymeric \\
\hline Capacity (kWh) & 28 \\
\hline Power $(\mathrm{kW})$ & 98 \\
\hline \multicolumn{2}{|c|}{ Results } \\
\hline Maximum speed $(\mathrm{km} / \mathrm{h})$ & 165 \\
\hline Acceleration $0-100 \mathrm{~km} / \mathrm{h}(\mathrm{s})$ & 9.9 (sport mode) / 10.2 (normal mode) \\
\hline Efficiency $(\mathrm{kWh} / 100 \mathrm{~km})$ & 11.5 \\
\hline Range $(\mathrm{km})$ & 280 \\
\hline \multicolumn{2}{|c|}{ Charging } \\
\hline DC charger $400 \mathrm{~V}$ (mode IV) & $30 \min$ (up to $80 \%$ of capacity) \\
\hline AC charger $400 \mathrm{~V}$ (mode II) & $4.5 \mathrm{~h}$ \\
\hline AC charger $230 \mathrm{~V}$ (included - mode I) & $12 \mathrm{~h}$ \\
\hline
\end{tabular}


Tab. 2. Basic data of Nissan LEAF electric car [10]

\begin{tabular}{|l|l|}
\hline \multicolumn{2}{|c|}{ Electric motor } \\
\hline Type & $\mathrm{A} / \mathrm{C}$ \\
\hline Effective power $(\mathrm{kW})$ & 120 \\
\hline Torque $(\mathrm{Nm})$ & 254 \\
\hline \multicolumn{2}{|c|}{ Battery } \\
\hline Type of battery & Lithium-ion \\
\hline Capacity $(\mathrm{kWh})$ & 24 \\
\hline Voltage $(\mathrm{V})$ & 360 \\
\hline & Results \\
\hline Maximum speed $(\mathrm{km} / \mathrm{h})$ & 144 \\
\hline Acceleration $0-100 \mathrm{~km} / \mathrm{h}(\mathrm{s})$ & 11.5 \\
\hline Energy consumption $(\mathrm{Wh} / \mathrm{km})$ & 150 \\
\hline Range $(\mathrm{km})$ & 199 \\
\hline & Charging \\
\hline Fast charging & 30 min (up to $80 \%)$ \\
\hline Standard charging & $8 \mathrm{~h}$ \\
\hline EVSE wire & $12 \mathrm{~h}$ \\
\hline
\end{tabular}

Tab. 3. Basic data of Tesla Model S electric car [12]

\begin{tabular}{|l|l|}
\hline \multicolumn{2}{|c|}{ Electric motor } \\
\hline Type & Asynchronous motor \\
\hline Effective power $(\mathrm{kW})$ & 386 \\
\hline Torque $(\mathrm{Nm})$ & 525 \\
\hline & \multicolumn{1}{|c|}{ Battery } \\
\hline Type of battery & Lithium-ion \\
\hline Capacity $(\mathrm{kWh})$ & 70 \\
\hline Power $(\mathrm{kW})$ & 245 \\
\hline & Results \\
\hline Maximum speed $(\mathrm{km} / \mathrm{h})$ & 230 \\
\hline Acceleration $0-100 \mathrm{~km} / \mathrm{h}(\mathrm{s})$ & 5.4 \\
\hline Electricity consumption $(\mathrm{kWh} / 100 \mathrm{~km})$ & 21 \\
\hline Range $(\mathrm{km})$ & 442 \\
\hline & Charging \\
\hline Fast charging & $30 \mathrm{~min}$ up to $80 \%$ \\
\hline Standard charging & $10 \mathrm{~h}$ \\
\hline
\end{tabular}

\section{Energy consumption by electric cars}

During testing and developing the energy balance of an electric car, factors such as energy consumption and efficiency of individual components should be taken into account, including, among others, electric drive - battery motors. It should also take into account all electronic devices (chargers, inverters) located in the electric energy conversion path from the power plant to the vehicle wheels, and take into account other elements of electrical equipment in the car such as displays, clocks, backlight diodes, but also the air-conditioning system or power steering system.

In the presented work, calculations of energy consumption by compared vehicles during the NEDC test were carried out (Fig. 4.). 


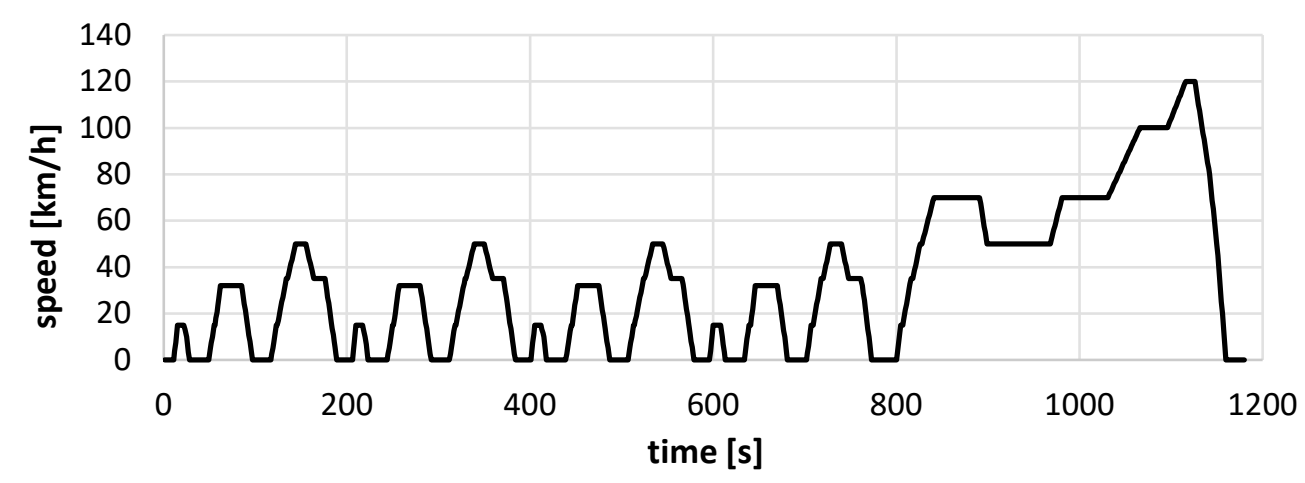

Fig. 4. NEDC test

The calculations used data of compared cars affecting the level of energy consumed by the vehicle - in accordance with the system of forces applied on the vehicle and the demand for rotational speed and engine torque (traction characteristic). The energy demand was calculated for a $100 \mathrm{~km}$ section (about 9 NEDC test lengths). The assumed conditions did not include energy recovery from braking. The energy that has been determined is the electric energy needed to accelerate the car and its driving at a constant speed, as well as to overcome the resistance, friction and inertia. The results are shaped in the following way [13]:

- Hyundai IONIQ ELECTRIC - $13.22 \mathrm{kWh} / 100 \mathrm{~km}$,

- Nissan LEAF - $13.66 \mathrm{kWh} / 100 \mathrm{~km}$,

- Tesla Model S - $17.12 \mathrm{kWh} / 100 \mathrm{~km}$.

The above values are related to the energy transferred from the vehicle's wheels to the road. Because in electric cars, the number of elements in the energy conversion chain is quite large, the appropriate efficiency (Tab. 4) necessary to calculate the energy generated by the power plant has been adopted to ensure that individual vehicles can drive over the $100 \mathrm{~km}$ section.

Tab. 4. Efficiency of car charging energy transfer chain [7, 13]

\begin{tabular}{|c|l|c|}
\hline No. & \multicolumn{1}{|c|}{ Step of electric energy transfer } & Efficiency [\%] \\
\hline 1. & Electric grid - energy transfer & 88 \\
\hline 2. & Car battery charger & 90 \\
\hline 3. & Battery & 95 \\
\hline 4. & Electric motor controller -inverter & 90 \\
\hline 5. & Electric motor & 90 \\
\hline 6. & Transmission & 93 \\
\hline
\end{tabular}

The total efficiency of the energy conversion system for electric cars in the power plant-tovehicle's wheel transformation system was estimated at $57 \%$. The efficiency of a coal-fired power plant is approx. $40 \%$. The efficiency of the entire energy conversion chain from obtaining fuel (coal, gas) to an electric car is at $20 \%$.

The amount of energy generated in the power plant needed to enable individual vehicles to drive the distance of $100 \mathrm{~km}$ in the NEDC test was:

1. Hyundai IONIQ ELECTRIC - $24.12 \mathrm{kWh} / 100 \mathrm{~km}$;

2. Nissan LEAF - $23.32 \mathrm{kWh} / 100 \mathrm{~km}$;

3. Tesla Model $\mathrm{S}-30.21 \mathrm{kWh} / 100 \mathrm{~km}$.

\section{Production of energy and toxic compounds by power plants}

Energy for car charging points is supplied by utility power plants, which in Poland are mostly based on the combustion of lignite or bituminous coal. A coal-fired power plant is a thermal and 
steam power plant. In the combustion processes, fumes are emitted into the atmosphere by the flue gas treatment system; and create pollution associated with the consumption of the appropriate amount of energy through a connected receiver.

The fumes affect not only the atmospheric air, but also the soil and water. Current standards (Emission Standards, BAT Conclusions) are increasingly limiting the amount of toxic components and dust in the flue gas coming from the power plant. Unfortunately, even modern exhaust gas cleaning systems do not allow 100\% reduction of toxic compounds emission in exhaust gases from energy sources. Tab. 5 presents types of pollutants that may come from the combustion of individual types of coal prepared on the basis of [1,2]. Regarding [1], the emission levels of individual components were adopted in relation to combustion processes in the energy production and transformation sector. There is an assumption of electrical energy production from non-renewable sources at 149.4 TWh [5].

Tab. 5. Levels of emissions of chemical compounds related to the combustion process in the energy production and transformation sector, and emission rates for electricity in $2016 \mathrm{~kg} /$ year

\begin{tabular}{|c|l|c|c|c|}
\hline No. & \multicolumn{1}{|c|}{ Exhaust gas component } & $\begin{array}{c}\text { Level of emission } \\
\mathrm{kg} / \text { year [1] }\end{array}$ & $\begin{array}{c}\text { Emission coefficient } \\
\mathrm{kg} / \mathrm{MWh}(\text { calculated) }\end{array}$ & $\begin{array}{c}\text { Emission coefficient } \\
\mathrm{kg} / \mathrm{MWh}[2]\end{array}$ \\
\hline 1. & Carbon monoxide $(\mathrm{CO})$ & 49773800.0 & 0.333 & 0.26 \\
\hline 2. & Carbon dioxide $(\mathrm{CO} 2)$ & - & - & 806.00 \\
\hline 3. & Nitrogen oxides $\left(\mathrm{NOx} / \mathrm{NO}_{2}\right)$ & 179478000.0 & 1.201 & 0.85 \\
\hline 4. & Sulphur oxides $\left(\mathrm{SOx} / \mathrm{SO}_{2}\right)$ & 261170100.0 & 1.748 & 0.84 \\
\hline 5. & Chrome $(\mathrm{Cr})$ & 6353.3 & 0.000043 & - \\
\hline 6. & Copper $(\mathrm{Cu})$ & 18156.3 & 0.000122 & - \\
\hline 7. & Mercury $(\mathrm{Hg})$ & 5184.0 & 0.000035 & - \\
\hline 8. & Nickel $(\mathrm{Ni})$ & 34727.9 & 0.000232 & - \\
\hline 9. & Zinc $(\mathrm{Zn})$ & 86405.6 & 0.000578 & 0.054 \\
\hline 10. & Particulate matters $\mathrm{PM}$ & 27146400.0 & 0.182 & - \\
\hline 11. & Arsenic $(\mathrm{As})$ & 5106.9 & 0.000034 & \\
\hline
\end{tabular}

Tab. 6. Calculated emission values of exhaust components for electric cars

\begin{tabular}{|c|c|c|c|c|c|c|c|c|}
\hline \multirow{2}{*}{ No. } & \multirow{2}{*}{ Exhaust gas component } & \multicolumn{3}{|c|}{ Emission in $\mathrm{g} / \mathrm{km}$} & \multicolumn{3}{|c|}{$\begin{array}{l}\text { Emission in comparison } \\
\text { to Euro } 6[\%]\end{array}$} & \multirow{2}{*}{$\begin{array}{c}\text { Euro } 6 \\
\mathrm{~g} / \mathrm{km}\end{array}$} \\
\hline & & Nissan & Hyundai & Tesla & Nissan & Hyundai & Tesla & \\
\hline 1. & Carbon monoxide $(\mathrm{CO})$ & 0.0714 & 0.0692 & 0.0895 & 7.15 & 6.92 & 8.96 & 1 \\
\hline 2. & Carbon dioxide $\left(\mathrm{CO}_{2}\right)$ & 194.2 & 188.0 & 243.4 & 149.4 & 144.6 & 187.3 & $130^{*}$ \\
\hline 3. & Nitrogen oxides $\left(\mathrm{NO}_{\mathrm{x}} / \mathrm{NO}_{2}\right)$ & 0.247 & 0.239 & 0.310 & 412.0 & 398.7 & 516.3 & 0.06 \\
\hline 4. & Sulphur oxides $\left(\mathrm{SO}_{\mathrm{x}} / \mathrm{SO}_{2}\right)$ & 0.421 & 0.408 & 0.528 & & & & \\
\hline 5. & Chrome $(\mathrm{Cr})$ & $1.02 \mathrm{E}-05$ & 9.92E-06 & $1.28 \mathrm{E}-05$ & & & & \\
\hline 6. & Copper $(\mathrm{Cu})$ & 2.93E-05 & $2.83 \mathrm{E}-05$ & $3.67 \mathrm{E}-05$ & & & & \\
\hline 7. & Mercury $(\mathrm{Hg})$ & $8.36 \mathrm{E}-06$ & $8.09 \mathrm{E}-06$ & $1.05 \mathrm{E}-05$ & & & & \\
\hline 8. & Nickel (Ni) & $5.6 \mathrm{E}-05$ & 5.42E-05 & $7.02 \mathrm{E}-05$ & & & & \\
\hline 9. & Zync (Zn) & 0.000139 & 0.000135 & 0.000175 & & & & \\
\hline 10. & Particulate matters PM & 0.0438 & 0.0424 & 0.0549 & 875.8 & 847.6 & 1097.7 & 0.005 \\
\hline 11. & Arsenic (As) & 8.24E-06 & 7.97E-06 & $1.03 \mathrm{E}-05$ & & & & \\
\hline
\end{tabular}

*limit issued in $2015[3,4]$ 
Table 6 shows the calculated emissions of individual exhaust components in relation to the energy generated in the Polish Power System needed to charge traction batteries of individual electric cars to a level that allows covering a distance of $100 \mathrm{~km}$, according to the NEDC test in accordance with the methodology presented in Chapter 2. There is a visible emission increase of some components in relation to a vehicle powered by a classical internal combustion engine.

Based on the above we can state that the electric vehicle, despite many undoubted advantages in the case of electricity production from coal, has a very negative impact on our health. Despite significant progress in the field of pollution control on the so-called end of the pipe (i.e. on the chimneys of the power plant), thanks to the installation of dust electrostatic precipitators or desulphurisation and denitrification installations - coal-fired power plants still release huge amounts of substances harmful to man and the environment.

\section{Conclusions}

1) Electric cars are seen as ecological means of transport. However, if they are charged from nonrenewable energy sources working on fossil fuels, this means the emission of toxic compounds by the power plant into the atmosphere.

2) Comparison of three electric cars indicates quite similar energy needs necessary to drive over a specific road section, while due to the low efficiency of the energy conversion chain between the power plant and the road, the amount of energy generated in the power plant must be almost twice as high, as the energy needed to overcome the resistance of the vehicles. The indications for the Tesla car are slightly larger due to the greater effort of the propulsion system (the vehicle is sport car).

3) The calculated emission values for individual electric cars indicate that while in the scope of carbon monoxide emission the Euro 6 standard is met, it is repeatedly exceeded in relation to the emission of nitrogen oxides and particulates (particulate matter). In the case of nitrogen oxides, the emission standard is exceeded about 5 times and in the case of particulate matter, up to 10 times.

4) The carbon dioxide emission limit introduced in 2015 for newly registered vehicles is exceeded by $50-90 \%$, depending on the vehicle's performance.

5) The values of emission factors for heavy metals have been quoted to indicate the level associated with the operation of electric cars.

\section{References}

[1] Krajowy bilans emisji $\mathrm{SO}_{2}, \mathrm{NO}_{X}, \mathrm{CO}, \mathrm{NH}_{3}, \mathrm{NMLZO}$, pyłów, metali ciężkich i TZO za lata 2015-2016, raport syntetyczny, KOBiZE, Warszawa, Styczeń 2018.

[2] Wskaźniki emisyjności $\mathrm{CO}_{2}, \mathrm{SO}_{2}, \mathrm{NO}_{x}, \mathrm{CO}$ i pylu całkowitego dla energii elektrycznej, KOBiZE, Warszawa, Grudzień 2017.

[3] https://kaizenfleet.pl/nowe-normy-co2-odmienia-branze-motoryzacyjna/ $\mathrm{z}$ dnia 10.07.2019.

[4] http://moto.pl/MotoPL/7,88389,23277145, unia-europejska-przycina-emisje-co2-pociagnieto-za-soba-nizsze.html z dnia 10.07.2019.

[5] Zestawienie danych ilościowych dotyczacych funkcjonowania KSE w 2016 roku, Raport 2016 KSE, Polskie Sieci Energetyczne, 2016.

[6] Liczba pojazdów zarejestrowanych w Polsce wg danych CEPiK (8.08.2017), Prawo drogowe 10.07.2017.

[7] https://www.rp.pl/artykul/649811-Straty-w-przesyle-siegaja-w-kraju-12-proc-energiirocznie. html, on the 25.06.2019.

[8] https:/www.drivezero.com.au/cars/hyundai/hyundai-car-guides/hyundai-ioniq-guide/, 09.07.2019.

[9] https://commons.wikimedia.org/wiki/File:Nissan_Leaf_ZE1_Nissan_Global_Headquarters_ Gallery_2017-08_1.jpg, 10.07.2019. 
[10] https://www.auto-data.net/pl/nissan-leaf-ii-ze1-40-kwh-150hp-32049, 10.07.2019.

[11] https://www.motofakty.pl/artykul/tesla-model-s-po-liftingu.html, 10.07.2019.

[12] https://pl.wikipedia.org/wiki/Tesla_Model_S, 10.07.2019.

[13] Brodowski, S., Analiza emisji związków toksycznych $w$ aspekcie eksploatacji wybranego pojazdu z napędem elektrycznym, Praca dyplomowa, WAT 2018.

Manuscript received 22 July; approved for printing 09 December 2019 